Anal. Real Acad. Nac. Farm., 2005, 71: 283-319

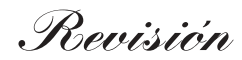

\title{
Purinergic signalling: therapeutic potential *
}

\author{
GEOFFREY BURNSTOCK \\ Académico Correspondiente de la Real Academia Nacional \\ de Farmacia
}

\begin{abstract}
The concept of a purinergic signalling system, using purine nucleotides and nucleosides as extracellular messengers, was first proposed over 30 years ago. After a brief introduction and update of purinoceptor subtypes, this article focuses on the diverse pathophysiological roles of ATP, ADP, UTP and adenosine. These molecules mediate short-term (acute) signalling functions in neurotransmission, secretion and vasodilatation and long-term (chronic) signalling functions in development, regeneration, proliferation and cell death. Plasticity of purinoceptor expression in pathological conditions is frequently observed, including an increase in the purinergic component of parasympathetic nervous control of the human bladder in interstitial cystitis and outflow obstruction, and in sympathetic cotransmitter control of blood vessels in hypertensive rats. The antithrombotic action of clopidogrel, a $\mathrm{P} 2 \mathrm{Y}_{12}$ receptor antagonist, has been shown to be particularly useful in the prevention of recurrent strokes and heart attacks in recent clinical trials. The role of $\mathrm{P} 2 \mathrm{X}_{3}$ receptors in nociception and a novel hypothesis about purinergic mechano-sensory transduction in visceral pain will be considered, as well as the therapeutic potential of purinergic agonists or antagonists for the treatment of supraventricular tachycardia, cancer, dry eye, bladder hyperactivity, erectile dysfunction, osteoporosis, diabetes, gut motility, respiratory and vascular disorders.
\end{abstract}

Key words: Purinoceptors._-Interstitial cystitis._-Thrombosis._-Visceral pain._Cancer.-Osteoporosis.-Peripheral vascular disease.—Cystic fibrosis.—Parkinson's disease.-Kidney failure.

Discurso de Toma de Posesión como Académico Correspondiente de la Real Academia Nacional de Farmacia pronunciado el día 2 de diciembre de 2004. 


\section{RESUMEN}

El concepto de un sistema de señalización purinérgica, empleando los nucleótidos y nucleósidos de purina como mensajeros extracelulares, fue propuesto hace unos 30 años. Después de una breve introducción y puesta al día de los subtipos de receptores purinérgicos, este artículo se centra en los aspectos fisiopatológicos desempeñados por el ATP, ADP, UTP y adenosina. Estas moléculas median respuestas a corto plazo (agudas), como en la neurotransmisión, secreción y vasodilatación, y también respuestas a largo plazo (crónicas), como la señalización en el desarrollo, regeneración, proliferación y muerte celular. En condiciones patológicas, se observa que la expresión de los purinoceptores es muy versátil, incluyendo un incremento en el componente purinérgico del control nervioso parasimpático de la vejiga humana en el caso de sufrir cistitis intersticial y obstrucción del flujo, y también como cotransmisor en el control simpático de los vasos sanguíneos en ratas hipertensas. La acción antitrombótica del clopidogrel, un antagonista del receptor $\mathrm{P} 2 \mathrm{Y}_{12}$, ha demostrado ser particularmente útil en la prevención de los infartos cerebrales recurrentes e infartos cardíacos en recientes ensayos clínicos. El papel del receptor $\mathrm{P}_{2} \mathrm{X}_{3}$ en la nocicepción y una nueva hipótesis sobre la transducción mecano-sensible en el dolor visceral, serán consideradas, así como el potencial terapéutico de los agonistas y antagonistas purinérgicos para el tratamiento de la taquicardia supraventricular, cáncer, ojo seco, hiperactividad de vejiga, disfunción eréctil, osteoporosis, diabetes, motilidad intestinal y anomalías respiratorias y vasculares.

Palabras clave: Purinoceptores.-Cistitis intersticial.-Trombosis.-Dolor visceral.-Cáncer.-Osteoporosis.-Enfermedad periférica vascular.-Fibrosis cística.-Enfermedad de Parkinson._-Fallo renal.

\section{INTRODUCTION}

A seminal paper by Drury and Szent-Györgi in 1929, described the potent actions of purine nucleotides and nucleosides, ATP and adenosine, on the heart and blood vessels. Then, in 1970, Burnstock and his colleagues found evidence for ATP as a neurotransmitter in non-adrenergic, non-cholinergic (NANC) nerves supplying the gut and in 1972 the word "purinergic» was coined and the purinergic neurotransmission hypothesis proposed by Burnstock in 1972. This concept met with considerable resistance for many years, because ATP had been established as an intracellular energy source involved in various metabolic cycles and it was thought that such a ubiquitous molecule was unlikely to be involved in selective extracellular signalling. However, the concept is now widely accepted. Later, it 
was established that ATP was a cotransmitter with classical transmitters in both the peripheral and central nervous systems, and that purines are also powerful extracellular messengers to nonneuronal cells, including exocrine and endocrine, secretory, endothelial, bone, immune and inflammatory cells (1).

Implicit in the purinergic hypothesis was the presence of purinoceptors (2). A basis for distinguishing P1 (adenosine) from P2 (ATP/ADP) receptors was proposed by Burnstock in 1978. This helped resolve some of the ambiguities in earlier reports, which were complicated by the breakdown of ATP to adenosine by ectoenzymes so that some of the actions of ATP were directly on $\mathrm{P} 2$ receptors, while others were due to indirect action via $\mathrm{P} 1$ receptors. Four subtypes of $\mathrm{P} 1$ receptors were cloned, namely $A_{1}, A_{2 A}, A_{2 B}$ and $A_{3}$ and in 1985, Burnstock and Kennedy proposed a basis for distinguishing two types of P2 purinoceptor, namely P2X and P2Y, based largely on pharmacological criteria. In the early 1990s, studies of transduction mechanisms and cloning of both $\mathrm{P} 2 \mathrm{X}$ and $\mathrm{P} 2 \mathrm{Y}$ receptors were carried out, which led Abbracchio and Burnstock to put forward a new nomenclature system in 1994, which is now widely accepted. They proposed that there were two families of P2 purinoceptors, namely $\mathrm{P} 2 \mathrm{X}$ ionotropic ligand-gated ion channel receptors and P2Y metabotropic G protein-coupled receptors. This framework has allowed a logical expansion as new receptors were identified. Currently seven subtypes of $\mathrm{P} 2 \mathrm{X}$ receptors and eight subtypes of $\mathrm{P} 2 \mathrm{Y}$ receptors are clearly recognized and their distribution in the body and pharmacological properties have been defined. The $\mathrm{P} 2 \mathrm{X}_{1}$ receptor is prominent in contractile smooth muscle cells, but is not detectable in proliferating smooth muscle cells, in which P2Y receptor expression is substantially increased.

Purinergic signalling is rapid in synaptic neurotransmission, neuromuscular transmission leading to contraction or relaxation of smooth muscle and in exocrine or endocrine secretion. However, there are now many examples of purinergic signalling regulating long-term events such as cell proliferation, differentiation, migration and death in development, regeneration and wound healing. Both P2X and P2Y receptors play prominent roles in embryonic development, including the nervous system, cartilage in limb buds, the mesonephros, retina, myotubes and neuromuscular junctions. 
There is increasing interest in the therapeutic potential of purinergic compounds in a wide range of disease conditions both in relation to $\mathrm{P} 1$ and $\mathrm{P} 2$ receptors. A number of purine-related compounds have been patented. The autonomic nervous system shows marked plasticity. Dramatic changes occur in the expression of cotransmitters and receptors during development and ageing, in nerves that remain after trauma or surgery and in disease conditions. There are several pathological conditions in which the cotransmission of purinergic components is increased. Readers are referred to recent reviews about the therapeutic potential of purinergic signalling $(3,4)$. Some of the statements made in this article are not supported by more recent reports because a limit of 40 references has been stipulated.

\section{CARDIOVASCULAR SYSTEM}

Adenosine and ATP are very much involved in the mechanisms underlying local control of vessel tone as well as cell migration, proliferation, differentiation and death during angiogenesis, atherosclerosis and restenosis following angioplasty (5). ATP, released as a cotransmitter from sympathetic nerves, constricts vascular smooth muscle via P2X receptors, while ATP released from sensory-motor nerves during "axon reflex» activity dilates vessels via P2Y receptors. Further, ATP released from endothelial cells during changes in flow (shear stress) or hypoxia acts on $\mathrm{P} 2 \mathrm{Y}$ receptors in endothelial cells to release nitric oxide (NO) resulting in relaxation. Adenosine, produced by the breakdown of extracellular ATP, causes vasodilatation via smooth muscle $\mathrm{P} 1$ receptors. $\mathrm{P} 2 \mathrm{X}$ receptors are also present on endothelial cells and appear to be associated with cell adhesion and permeability.

There have been very promising developments concerning purinergic antithrombotic drugs. Platelets are known to express both $\mathrm{P} 2 \mathrm{Y}_{1} \mathrm{P} 2 \mathrm{Y}_{12}$ and $\mathrm{P} 2 \mathrm{X}_{1}$ receptors. "Mega» clinical trials (CAPRIE and CURE) have provided clear evidence that the purinergic antithrombotic drugs clopidogrel and ticlopidine, which are antagonists to the platelet $\mathrm{P} 2 \mathrm{Y}_{12}$ receptor, reduce the risks of recurrent strokes and heart attacks, especially when combined with 
aspirin. There are genetic variations in $\mathrm{P} 2 \mathrm{Y}_{1}$ and $\mathrm{P} 2 \mathrm{Y}_{12}$ receptor gene sequences in healthy subjects that explain variations in the platelet response to ADP; this may reflect individual variation in atherothrombotic risk and the efficacy of purinergic antithrombotic drugs. Postoperative carotid thrombosis is a significant risk for stroke; it seems likely that clopidogrel or ticlopodine may provide an avenue for targeted antiplatelet therapy following vascular intervention. Platelet aggregation in response to ADP is significantly inhibited in patients with peripheral vascular disease two to four hours after a loading dose of clopidogrel. There is a synergistic interaction between ATP and noradrenaline in stimulating platelet aggregation, which suggests a prothrombotic role for ATP in stress. Leishmania-infected dogs show changes in haemocoagulative functions and there is a significant decrease in ADP- and collageninduced platelet aggregation. Platelet activation that occurs in human acute malaria infection is associated with elevated plasma ATP concentrations.

Upregulation of $\mathrm{P} 2 \mathrm{X}_{1}$ and $\mathrm{P} 2 \mathrm{Y}_{2}$ receptor $\mathrm{mRNA}$ in the hearts of rats with congestive heart failure has been reported. ATP and adenosine are widely used for the treatment of paroxysmal supraventricular tachycardia in both infants and adults. The substantial enhancement of mechanical performance with 2-deoxyATP in cardiac muscle suggests that it may be a better substrate for contractility than ATP and suggests that ribonucleotide reductase may be a target for therapy in heart failure. Enhanced adrenergic activity causes cardiac dysfunction, arrhythmias and sudden cardiac death in myocardial ischaemia; a novel role for the ectonucleotidase, E-NTPDase 1 or CD39 (an ectoADPase), at sympathetic nerve terminals may offer a novel therapeutic approach to hyperadrenergic states such as myocardial ischaemia and its consequences and since it also inhibits platelet aggregation, for the treatment of thrombotic diatheses. ATP was shown to inhibit atrioventricular conduction rather than the firing rate of sinoatrial nodes in patients with ischaemic heart disease; injection of ATP is used only when a transient cardiac standstill was needed, such as for endovascular grafting surgery. The implantable cardioventer defibrillator reduces the mortality of patients with ventricular arrhythmias. Employing transgenic overexpression of human $\mathrm{P}_{2} \mathrm{X}_{4}$ receptors, cardiac $\mathrm{P} 2 \mathrm{X}_{4}$ 
receptors have been shown to have a beneficial life-prolonging role in heart failure; increased expression or activation of these ATPstimulated receptor channels may represent a new therapeutic approach to the treatment of heart failure (6). Administration of ATP during sinus rhythm has been suggested as a useful bedside test for identifying patients with concealed accessory pathway who are prone to atrioventricular reentrant tachycardia.

ATP release from red blood cells is increased in pathological conditions such as subarachnoid haemorrhage, largely because there is widespread blood cell lysis. This leads to transient constriction of arterioles via $\mathrm{P} 2 \mathrm{X}$ receptors and a sustained constriction of large cerebral vessels, largely through $\mathrm{P}_{2} \mathrm{Y}_{2}$ receptors. The differences in purinergic receptor distribution between macro- and microvessels in the cerebral circulation are likely to have important consequences in pathological conditions. In contrast, red blood cells of humans with primary pulmonary hypertension, fail to release ATP in response to mechanical deformation. This is likely to result in the loss of local control of total pulmonary vascular resistance in the lung.

Magnesium-ATP has been recommended for the treatment of ischaemia, radiation injury, shock and sepsis for many years. Treatment of myocardial ischaemia and reperfusion by ATP- $\mathrm{MgCl}_{2}$ is still recommended, but many reports suggest that adenosine (a break-down product of ATP) also mediates this effect. Diadenosine tetraphosphate $\left(\mathrm{AP}_{4} \mathrm{~A}\right)$ protects against injuries induced by ischaemia and 6-hydroxytryptamine in rat brain and has beeen suggested as a potentially useful target molecule in the therapy of stroke and Parkinson's disease. Upregulation of $\mathrm{P} 2 \mathrm{X}_{2}$ and $\mathrm{P} 2 \mathrm{X}_{4}$ receptors in organotypic cultures of hippocampus, cortex and striatum is associated with ischaemic cell death and was prevented by P2 receptor antagonists. The protective effect of ATP- $\mathrm{MgCl}_{2}$ in ischaeamia-reperfusion lung injury appears to require the presence of leukocytes.

ATP plays a significant cotransmitter role in sympathetic nerves supplying hypertensive blood vessels. The purinergic component is increased in SHR (2). ATP is a rapidly acting hypotensive agent that compares favourably with sodium nitroprusside. ATP- $\mathrm{MgCl}_{2}$ is a safe, 
effective and preferential pulmonary vasodilator in children with pulmonary hypertension secondary to congenital heart defects; it has also been used for treating pulmonary hypertension after cardiac surgery. EPA, one of the active components in fish oil that has antihypertensive effects, increases the release of ATP from vascular endothelial cells leading to reduction of the blood pressure rise characteristic of ageing.

Varicose veins are characterised by hypoxia, inflammation and cell death, all likely to lead to increases in extracellular ATP. $\mathrm{P} 2 \mathrm{X}_{1}$ and $\mathrm{P} 2 \mathrm{X}_{7}$ receptors are expressed by saphenous vein smooth muscle and it has been suggested that resultant $\mathrm{P} 2 \mathrm{X}_{7}$ receptor activation contributes to the decrease in contractile myocytes and resulting disorganisation of the vessel wall. P2 receptors have been proposed as potential new players in atherosclerosis (7). Large clinical trials with clopidogrel and ticlodipine $\left(\mathrm{P}_{2} \mathrm{Y}_{12}\right.$ receptor antagonists) in patients with atherosclerotic disease have shown significant benefit compared with aspirin.

Saphenous vein, internal mammary and radial arteries have been used as grafts for coronary bypass surgery; the level of endothelial $\mathrm{P}_{2} \mathrm{Y}_{2}$ receptors is comparable in all three vessels, but endothelial $\mathrm{P} 2 \mathrm{X}_{4}$ receptors vary from high in saphenous vein to significantly lower in the other two vessels. It has been suggested that $\mathrm{P} 2 \mathrm{X}_{4}$ receptors play a more significant role in intense proliferation in arteriosclerosis and restenosis in the $\mathrm{P}_{2} \mathrm{Y}_{2}$ receptors reflected by susceptibility of saphenous vein grafts to atherosclerosis compared to internal mammary arteries. In another study, $\mathrm{P} 2 \mathrm{X}_{1}$ and $\mathrm{P} 2 \mathrm{Y}_{6}$ receptors mediate more prominent contractions in the saphenous vein compared to the internal mammary artery; it has been suggested that selective antagonists to these receptors may prevent vasospasm and restenosis in the saphenous vein during and after revascularisation surgery. A novel role for the $\mathrm{P}_{2} \mathrm{Y}_{2}$ receptors has been suggested whereby UTP induces vascular cell adhesion molecule-1 expression in coronary artery endothelial cells that mediates the recruitment of monocytes; this may be associated with the development of atherosclerosis. The long-term (trophic) roles of purinergic signalling in vascular smooth muscle and endothelial cell proliferation and death, have been implicated in atherosclerosis and restenosis and suggest the exploration of therapeutic strategies in relation to these events (5). 
It has been proposed that there is prognostic value of stress myocardial perfusion imaging using ATP at the beginning of haemodialysis treatment in patients with end-stage renal disease.

\section{DERMATOLOGY}

Purinergic signalling is much involved in keratinocyte turnover in skin epidermis: $\mathrm{P} 2 \mathrm{Y}_{1}$ and $\mathrm{P}_{2} \mathrm{Y}_{2}$ receptors in basal and parabasal layers mediate cell proliferation; $\mathrm{P} 2 \mathrm{X}$ receptors in the granular layer mediate cell differentiation; and $\mathrm{P} 2 \mathrm{X}_{7}$ receptors at the stratum granulosum/stratum corneum border mediate apoptosis (8). There are changes in the expression of $\mathrm{P} 2$ receptors in proliferative disorders of the epidermis, including psoriasis and scleroderma and $\mathrm{P}_{2} \mathrm{Y}_{2}$ receptors have been proposed as a novel target for therapy of these disorders.

There is an increase of $\mathrm{P} 2 \mathrm{X}_{3}$ and $\mathrm{P} 2 \mathrm{X}_{2 / 3}$ nociceptive receptors on sensory nerve endings in inflamed skin and antagonists are being developed as analgesics (see section on Pain); data have been presented to support a pathogenic role for keratinocyte-derived ATP in irritant dermatitis.

Changes in expression of purinergic receptors in the regenerating epidermis in wound healing have been described. The P2X receptor antagonist, PPADS, has been shown to accelerate skin barrier repair and prevent epidermal hyperplasia induced by skin barrier disruption.

\section{Purinergic signalling involved in skin tumours is discussed in the section on Oncology.}

\section{DIABETES}

Early studies from the laboratory of Loubatières-Mariani showed that $\mathrm{P} 2 \mathrm{Y}$ receptors are present on pancreatic b-cells and are involved in insulin secretion. ATP stimulates pancreatic insulin release through a glucose-dependent $\mathrm{P} 2 \mathrm{Y}$ receptor-mediated mechanism, and also modulates insulin secretion through interactions with 
ATP-sensitive potassium channels in islet b-cells. Biotin enhances ATP synthesis in pancreatic islets, resulting in reinforcement of glucose-induced insulin secretion.

P2Y purinoceptors appear to be impaired in fibroblasts from Type 2 diabetic patients, which results in reduced glucose (GLUT 1) uptake, suggesting that $\mathrm{P} 2 \mathrm{Y}$ receptors may be candidate targets for the design of innovative antidiabetic drugs. Hormone-specific defects in insulin regulation of ATPase is seen in non-insulin-dependent diabetic rats that may contribute to their insulin resistance.

A feature of diabetic retinopathy is the apoptotic death of microvascular pericytes and endothelial cells; there appears to be an enhancement of $\mathrm{P} 2 \mathrm{X}_{7}$-induced pore formation and apoptosis in early diabetes on the retinal microvasculature. In streptozotocin-diabetic animals, $\mathrm{P} 2 \mathrm{X}_{7}$ receptor expression, located in glucagon-containing a cells in pancreatric islets, increases and migrates centrally to take the place of the insulin-containing b-cells, although the functional significance of this is not known. The potential role of purinergic compounds as novel treatments for diabetes has yet to be explored. Stimulation of insulin secretion and improvement of glucose tolerance in rats and dogs by the P2Y receptor agonist adenosine-5'(2-thiodiphosphate) has been claimed.

\section{ENDOCRINE AND FAT CELLS}

Purinoceptors are widely expressed in endocrine glands (1). For example, ATP and UTP increase cystolic free calcium in human thyrocytes, ATP modulates aldosterone production by adrenal cortex, ATP regulates prolactin release from anterior pituitary and vasopressin and oxytocin secretion from posterior pituitary. ATP stimulates insulin release from endocrine pancreas, ATP and UTP inhibit oestrodial and progesterone secretion from the ovary and mediate increases in intracellular calcium in Sertoli cells from testis. Recent observations reveal a wide diversity of actions of purines in the pituitary, including trophic effects and cytokine production as well as actions in hormone release, with implications for pathological as well as physiological states. 
ATP, released as a cotransmitter from sympathetic nerves, has been shown to stimulate brown adipocytes. Deficits in receptor regulation, transporter mobilization and adipocyte hormone secretion are all thought to contribute to the pathology of obesity. A recent paper described stimulation of lipogenesis in rat adipocytes by ATP, which regulates fat stores independently from established hormones.

\section{GASTROENTEROLOGY}

Purinergic signalling plays a major role in different activities of the gut (9). ATP is a cotransmitter in NANC nerves responsible for the inhibitory phase in peristalsis; it participates in synaptic transmission in the myenteric and submucosal ganglia; it is involved in vascular control of the gastrointestinal tract and in the control of mucosal secretion. Both glial cells and interstitial cells of Cajal express $\mathrm{P} 2$ receptors, although their roles have yet to be clarified.

A limited number of studies have been conducted to date on changes in purinergic signalling in the diseased gut. ATP and adenosine have been implicated in the development of gastric ulcers, Hirschsprung's and Chagas' diseases, ischaemia and colonic tumours (9). Extracellular nucleotides and their receptors have been implicated in the pathogenesis of inflammatory bowel disease (IBD). $\mathrm{T}$ cells are thought to play a primary role in the induction of epithelial cell damage in IBD and the $\mathrm{P} 2 \mathrm{Y}_{6}$ receptor was found to be highly expressed on the T cells infiltrating IBD, but absent in $\mathrm{T}$ cells of unaffected bowel. This suggests that $\mathrm{P}_{2} \mathrm{Y}_{6}$ receptor and its selective agonists, may play a role in the pathogenesis of IBD. Later papers have shown that $\mathrm{P}_{2} \mathrm{Y}_{6}$ receptors are involved in monocytic release of IL- 8 and stimulation of $\mathrm{NaCl}$ secretion. $\mathrm{P} 2 \mathrm{X}_{3}$ receptor expression is increased in the enteric plexuses in human IBD, suggesting a potential role in dysmotility and pain. During inflammation of the gastrointestinal tract, glial cells proliferate and produce cytokines; thus, $\mathrm{P} 2 \mathrm{X}_{7}$ receptors may play a role in the response of enteric glia to inflammation. $\mathrm{P}_{2} \mathrm{X}_{3}$ purinergic signalling enhancement in an animal model of colitis has been described (10). A recent paper has raised the possibility that $\mathrm{P} 2 \mathrm{X}$ receptors are potential targets 
for the drug treatment of irritable bowel syndrome (11). Bile induces ATP depletion and contributes to the early mucosal permeability alteration and barrier lesions that occur during experimental oesophageal reflux. $\mathrm{P}_{2} \mathrm{X}_{3}$ immunohistochemistry has been demonstrated in aganglionic bowel in Hirschsprung's disease, suggesting that the sensory nerves may form a significant proportion of its hypertrophic innervation. P2Y receptors in smooth muscle and ATP production in myenteric neurons increase in postoperative ileus, probably contributing to delayed colonic transit. An inhibitor of purinergic transmission, OrphaninFG, reversed postoperative ileus in rats and therefore may have therapeutic application. Recent reviews have highlighted the potential of purinergic drugs for the treatment of functional bowel disorders and visceral pain (11).

Intrinsic sensory neurones in the submucous plexus of the gut, as well as extrinsic sensory nerves, show positive immunoreactivity for $\mathrm{P} 2 \mathrm{X}_{3}$. It has been proposed (12) that during moderate distension, low threshold intrinsic enteric sensory fibres may be activated via $\mathrm{P} 2 \mathrm{X}_{3}$ receptors by ATP released from mucosal epithelial cells, leading to reflexes concerned with propulsion of material down the gut. Studies showing that peristalsis is impaired in the small intestine of mice lacking the $\mathrm{P} 2 \mathrm{X}_{3}$ subunit support this view. In contrast, during substantial (colic) distension associated with pain, higher threshold extrinsic sensory fibres may be activated by ATP released from the mucosal epithelia; these fibres pass messages through the dorsal root ganglia to pain centres in the central nervous system (10).

In the liver, purinergic receptors have been identified in the plasma membrane of the two principal epithelial cell types that form the bile secreting unit, namely hepatocytes, which constitute the liver parenchymal cells and cholangiocytes, which line the lumen of intrahepatic bile ducts. Activation of the receptors has been linked to several fundamental responses important to cellular metabolism, ion channel activation, cell volume regulation and bile formation. It is suggested that pharmacological modulation of ATP release and purinergic signalling might provide novel strategies for the management of cholestasis and other disorders characterised by impaired bile flow. Purinergic receptors are present on both quiescent and activated hepatic stellate cells; quiescent cells express 
$\mathrm{P}_{2} \mathrm{Y}_{2}$ and $\mathrm{P}_{2} \mathrm{Y}_{4}$ receptors activated by UTP and ATP, whereas activated cells express $\mathrm{P}_{2} \mathrm{Y}_{6}$ receptors activated by UDP and ATP. It has been speculated that the $\mathrm{P} 2 \mathrm{Y}$ receptors on satellite cells may be an attractive target to prevent or treat liver fibrosis, via regulation of procollagen-1 transcription. ATP has been shown recently to rapidly activate multiple components of the c-jun $\mathrm{N}$-terminal kinase (JNK) cascade, a central player in hepatocyte proliferation and liver regeneration. This study identifies extracellular ATP as a hepatic mitogen with implications about the regulation of liver growth and repair.

The effect of ATP on salivary glands has been recognised since 1982. Both P2X and P2Y subtypes are expressed and opportunities for utilization of these receptors as pharmaceutical targets for diseases involving salivary gland dysfunction appear promising.

\section{IMMUNE SYSTEM AND INFLAMMATION}

ATP and adenosine are released at sites of inflammation. ATP is involved in the development of inflammation through a combination of actions: release of histamine from mast cells, provoking production of prostaglandins, and the production and release of cyokines from immune cells. In contrast, adenosine exerts anti-inflammatory actions. $\mathrm{P} 2 \mathrm{X}_{7}$ and $\mathrm{P} 2 \mathrm{Y}_{1}$ and $\mathrm{P} 2 \mathrm{Y}_{2}$ receptors located on inflammatory and immune cells play a pivotal role in inflammation and immunomodulation (13).

In addition to the roles of purines in inflammation, they have a broad range of functions carried out through purinergic receptors on immune cells, including killing intracellular pathogens by inducing apoptosis of host macrophages, chemoattraction and cell adhesion. Purinergic compounds may turn out to be useful for the treatment of neurogenic inflammation, rheumatoid arthritis and periodontitis.

ATP-induced apoptosis in macrophages via $\mathrm{P} 2 \mathrm{X}_{7}$ receptors, also results in killing of the mycobacteria contained within them, in contrast, to the macrophage apoptoses produced by other agents; elucidation of the bacterial killing mechanism initiated by the $\mathrm{P} 2 \mathrm{X}_{7}$ 
receptor may help to devise new strategies to combat the most potent and enduring of human pathogens (14). Infection with $\underline{\mathbf{M}}$. tuberculosis causes macrophages to release ATP, which leads to oxygen-radical production, providing antibacterial effects at sites of infection. In later studies, it was shown that the ATP-induced bactericidal activity towards virulent $\underline{M}$. tuberculosis requires an increase in cytosolic $\mathrm{Ca}^{2+}$ in infected macrophages and it was hypothesised that the $\mathrm{Ca}^{2+}$-dependence was linked to promotion of phagosome-lysosome fusion. The $\mathrm{P} 2 \mathrm{X}_{7}$ receptor plays a fundamental role in lipopolysaccharide signal transduction and activation of macrophages and may therefore represent a therapeutic target for Gram-negative bacterial septicaemia. Vibrio cholerae, the causative organism of the intestinal disease cholera, secretes enzymes that lead to ATP degradation; this may allow the pathogen to evade the immune system by reducing the apoptotic actions of the $\mathrm{P}_{2} \mathrm{X}_{7}$ receptor. Evidence has been presented to support the view that, while the cytotoxic actions of ATP on macrophages was via $\mathrm{P} 2 \mathrm{X}_{7}$ receptors, the bacteriocidal effects of ATP (and UTP) were probably via P2 $\mathrm{Y}_{2}$ receptors.

ATP moderates anti-IgE-induced release of histamine from lung mast cells and may therefore be mechanistically involved in human allergic/asthmatic reactions. Alveolar macrophages express $\mathrm{P} 2 \mathrm{X}_{7}$ receptors, which upon stimulation trigger pro-inflammatory responses, including activation of IL1-6 cytokines and granulomatous reactions (15).

Extracellular ATP inhibits the activation of $\mathrm{CD}^{+} \mathrm{T}$ lymphocytes via P2Y receptors, which suggests a novel therapeutic target for topical immunosuppression in eye, skin or airway inflammatory disease. In addition to the apoptosis mediated by $\mathrm{P} 2 \mathrm{X}_{7}$ receptors, a lower level of activation sometimes results in cell proliferation; it has been suggested that the expression and function of $\mathrm{P} 2 \mathrm{X}_{7}$ receptors on B lymphocytes may correlate with the severity of B-cell chronic lympocytic leukaemia.

During the acute phase of Trypanosoma cruzi infection, the eteologic agent of Chagas' disease, thymic atrophy occurs; ATP also induces cell death in $\mathrm{CD} 4^{+} / \mathrm{CD} 8^{+}$double-positive thymocytes and may play a central role in thymus atrophy during $\underline{T}$. cruzi infection. 
Infection by the parasitic blood fluke Schistosoma mansoni also leads to thymic atrophy. The cloning and characterisation of a P2X receptor (schP2X) from Schistosoma mansoni provides the first example of a non-vertebrate ATP-gated ion channel and may provide an alternative drug target for the treatment of schistosomiasis.

A novel mechanism by which ATP, probably via $\mathrm{P}_{2} \mathrm{Y}_{11}$ receptors, can regulate the trafficking of specific dendritic cell populations has been described. The migration of dendritic cells from the site of antigen capture to lymphoid tissue is a prerequisite for the induction and regulation of immune responses. Therefore, ATP-mediated inhibition of migration could play an important role in inflammatory disease and cancer. Targeting of $\mathrm{P} 2 \mathrm{Y}_{11}$ receptors may provide a new therapeutic strategy to improve the migration of dendritic cells to induce the trafficking of antigen from the vaccine site to the draining lymph nodes.

Allopurinal and captopril have a therapeutic effect on granulomatous disorders, such as sarcoidosis, by a direct action on monocyte/macrophage lineage cells partly by downregulation of intracellular adhesion molecular-1 (ICAM-1) and $\mathrm{P} 2 \mathrm{X}_{7}$ receptors. ATP and UTP have been shown to be potent stimulators of human haematopoietic stem cells both in vitro and in vivo. Thus, these extracellular nucleotides may provide a novel and powerful tool to modulate haematopoietic stem cell function to increase the number of transplantable cells in vivo in the event of bone marrow failure. $\mathrm{P} 2 \mathrm{X}_{7}$ receptors control endocannabinoid production by microglia cells and might constitute promising therapeutics to temper exacerbated microinflammatory responses and allied cell damage.

\section{MIGRAINE}

Classical migraine is associated with two distinct cerebrovascular phases; an initial vasoconstriction (not associated with pain) followed by vasodilatation (reactive hyperaemia) associated with pain. The "purinergic" hypothesis for migraine was originally put forward by Burnstock in 1981 as a basis for the reactive hyperaemia and pain during the headache phase. It was suggested that ATP and its breakdown products adenosine 5'-monophosphate and adenosine 
were strong contenders for mediating the vasodilatation following the initial vasospasm and subsequent hypoxia. ATP was also implicated in the pathogenesis of pain during migraine via stimulation of primary afferent nerve terminals located in the cerebral vasculature. Recent studies have shown that the ATPinduced cerebral vasodilatation is endothelium-dependent via activation of P2Y-purinoceptors on the endothelial cell surface and subsequent release of endothelium-derived relaxing factor (EDRF); and that the endothelial cells are the main local source of ATP involved, although ADP and ATP released from aggregating platelets may also contribute to this vasodilatation. These findings have extended the "purinergic» hypothesis for migraine in two ways. Firstly, they have clarified the mechanism of purinergic vasodilatation during the headache phase of migraine. Secondly, they suggest that a purinergic mechanism may also be involved in the initial local vasospasm, via P2X-purinoceptors on smooth muscle cells occupied by ATP released either as a cotransmitter with noradrenaline from perivascular sympathetic nerves or from damaged endothelial cells. The hypothesis has gained further support by the identification of $\mathrm{P} 2 \mathrm{X}_{3}$ receptors on primary afferent nerve terminals arising from trigeminal, nodose and spinal ganglia (12). Thus, $\mathrm{P} 2 \mathrm{X}_{3}$ receptor antagonists may be candidates for antimigraine drug development (16). There is also recent evidence that migraine is a chronic sympathetic nervous system disorder, where there is an increase in release of sympathetic cotransmitters, including ATP, which may contribute to the initial vasospasm.

\section{MUSCULOSKELETAL SYSTEM}

Several reports implicate purinergic signalling in bone development and remodelling. $\mathrm{P} 2 \mathrm{X}$ and $\mathrm{P} 2 \mathrm{Y}$ receptors are present on osteoclasts, osteoblasts and chondrocytes (17). ATP, but not adenosine, stimulates the formation of osteoclasts and their resorptive actions in vitro, and can inhibit osteoblast-dependent bone formation. The bisphosphonate clodronate, which is used in the treatment of Paget's disease and tumour-induced osteolysis, may act through osteoclast P2 receptors. Very low (nM) concentrations of ADP acting through $\mathrm{P}_{2} \mathrm{Y}_{1}$ receptors turn on osteoclast activity. 
In a recent study, deletion of the $\mathrm{P} 2 \mathrm{X}_{7}$ receptor revealed its regulatory roles in bone formation and resorption. It reduces bone resorption by decreasing osteoclast survival (18). The multiple purinoceptors on bone and cartilage also represent potential targets for the development of novel therapeutics to inhibit bone resorption in diseases such as rheumatoid arthritis, osteoporosis, tumourinduced osteolysis and peridontis.

Nucleotide metabolism is tightly controlled in the cartilage extracellar matrix. Apart from modulating purinoceptor activation, ectoenzymes can regulate the levels of extracellular phosphate and pyrophosphate, the components involved in crystal deposition. Mechanical stimulation, which is critical for the maintenance of healthy articular cartilage, can influence the rate of nucleotide release and metabolism. The repair of foetal, but not adult, articular cartilage involves the intercellular transfer of ATP, increase of $\left[\mathrm{Ca}^{2+}\right]_{i}$ and expression of cfos in cartilage.

Tendinosis is a disorder characterised by acute or chronic pain and degenerative change in the matrix. Mechanical loading induces ATP release from tendon cells and stimulates expression of interleukin IL-1 $\beta, \operatorname{Cox} 2$ and metalloproteinases as a negative feedback mechanism to limit activation of the injurious pathway. Attenuation of the feedback mechanism may result in the progression of tendinosis.

Ultrasound is often used to accelerate fracture healing. It has been shown recently that osteoblasts respond to ultrasound stimulation by increasing ATP release, which appears to mediate stimulation of osteoblast gene expression and cell proliferation.

A role for purinergic signalling in rheumatic diseases has been considered for some time. Quinacrine (Atabrine), a drug that binds strongly to ATP, has been used for the treatment of rheumatoid arthritis patients for many years, one of its mechanisms of action being to decrease levels of prostaglandin $E_{2}$ and Cox-2, which are known to be produced following occupation of $\mathrm{P} 2 \mathrm{Y}$ receptors by ATP. The articular fluid removed from arthritic joints contains high levels of ATP. Purinergic regulation of bradykinin-induced plasma extravasation and adjuvant-induced arthritis has been reported. ATP and UTP activate calcium-mobilizing $\mathrm{P} 2 \mathrm{Y}_{2}$ or $\mathrm{P} 2 \mathrm{Y}_{4}$ receptors and act 
synergistically with interleukin-1 to stimulate prostaglandin $\mathrm{E}_{2}$ release from human rheumatoid synovial cells. More recently, relief of inflammatory pain by the $\mathrm{P} 2 \mathrm{X}_{7}$ receptor antagonist, oxidized ATP, in arthritic rats has been reported (19). Spinal P1 receptor activation has been claimed to inhibit inflammation and joint destruction in rat adjuvant-induced arthritis, supporting the view that therapeutic strategies that target the CNS might be useful in arthritis. Suppression of experimental Zymosan-induced arthritis by intraperitoneal administration of adenosine has also been described.

Lymphoblastoid cells isolated from Duchenne muscular dystrophy patients are highly sensitive to stimulation by extracellular ATP. A recent study provides the first evidence for a role for purinergic signalling in muscle regeneration using the mdx mouse model of muscular dystrophy and raises the possibility of new therapeutic strategies for the treatment of muscle disease (20). Pain related to the musculoskeletal system (myofascial pain) is very common and ATP has been claimed to excite or sensitize myofascial nociceptors.

\section{NEPHROLOGY}

There is a substantial presence of purinoceptors in different regions of the nephron, the glomerulus and renal vascular system in the kidney, including subtypes involved in the regulation of renin secretion, glomerular filtration and the transport of water, ions, nutrients and toxins (21). ATP and adenosine have been used to protect kidneys from renal ischaemic-reperfusion injury, and are being explored for the treatment of chronic renal failure and transplantation-induced erythrocytosis. It has been proposed that luminal P2 receptors in the nephron are part of an epithelial «secretory» defence mechanism against bacteria or harmful particles involved in the regulation of cell volume when transcellular solute transport is out of balance. P2Y receptors mediate renin secretion. ATP released from macula densa cells, serves as the major paracrine agent mediating tabuloglomerular feedback signals to regulate afferent arteriolar resistance.

Cyclosporine is a potent immunosuppressive agent, but its use has been limited by the side effect of nephrotoxicity; however, ATP 
treatment after verapamil pre-treatment greatly reduces the nephrotoxic potential. The P2 receptor antagonist, PPADS, has been shown to be an effective inhibitor of mesangial cell proliferation in an experimental rat model of mesangial proliferative glomerulonephritis.

In polycystic kidney disease, tubules are altered, leading to dilated tubules or cysts encapsulated by a single monolayer of renal epithelium. It has been postulated that autocrine purinergic signalling may augment detrimentally cyst volume expansion, accelerating the disease progression. An increase in expression of $\mathrm{P} 2 \mathrm{Y}_{2}, \mathrm{P}_{2} \mathrm{Y}_{6}$ and $\mathrm{P} 2 \mathrm{X}_{7}$ receptors has been reported in cystic tissue from the Han: SPRDcy/+rat model of autosomal dominant polycystic kidney disease. P2 antagonists and inhibitors of ATP release are being explored as therapeutic agents to treat this disease. ATP may inhibit pathological renal cyst growth through $\mathrm{P} 2 \mathrm{X}_{7}$ signalling. There is increased glomerular expression of $\mathrm{P} 2 \mathrm{X}_{7}$ receptors in two rat models of glomerular injury due to diabetes and hypertension (22). A further study of human and experimental glomerulonephritis also shows increase in $\mathrm{P} 2 \mathrm{X}_{7}$ receptor expression.

Administration of ATP complexed with $\mathrm{MgCl}_{2}$ has been used for many years to improve post-ischaemic and drug-induced glomerular and tubular function. There is convincing evidence that there is increased sympathetic activity in renal disease, especially ischaemia. Since ATP is established as a cotransmitter with noradrenaline in sympathetic nerves, this may be a source of enhanced ATP in these conditions.

\section{NEUROLOGY}

ATP is a cotransmitter in many nerve types, probably reflecting the early evolutionary presence of purinergic signalling (23). There is now evidence for ATP as a cotransmitter with noradrenaline (NA) and neuropeptide Y (NPY) in sympathetic nerves, with acetylcholine and vasoative intestinal peptide (VIP) in some parasympathetic nerves, with nitric oxide (NO) and VIP in enteric NANC inhibititory nerves, and with calcitonin gene-related peptide (CGRP) and substance $\mathrm{P}$ in sensory-motor nerves. There is also evidence for 
the cotransmission of ATP with g-aminobutyric acid in retinal nerves, and with glutamate, 5-hydroxytryptamine (serotonin), NA or dopamine in nerves in the brain. In sympathetically innervated tissues, such as the vas deferens or blood vessels, ATP produces fast responses mediated by P2X receptors, followed by a slower component mediated by $\mathrm{G}$ protein-coupled a-adrenoceptors. Similarly, in the parasympathetic nerves supplying the urinary bladder, ATP provokes a fast transient resonse via $\mathrm{P} 2 \mathrm{X}$ receptors, while the slower component is mediated by $G$ protein-coupled muscarinic receptors. There are differences in the proportion of cotransmitters between species and in different pathophysiological conditions. $\mathrm{P} 2 \mathrm{X}_{3}$ receptors are selectively localised on sensory neurons in trigeminal, nodose and dorsal root ganglia (DRG), and the terminals of these nociceptive neurons in the skin and visceral organs represent unique targets for novel analgesic agents that function as $\mathrm{P} 2 \mathrm{X}_{3}$ receptor antagonists. Non-specific P2 receptor antagonists, eg suramin, are antinociceptive, and $\mathrm{P}_{2} \mathrm{X}_{3}$ receptor-knockout mice have reduced nociceptive inflammatory responses (12). The first clear evidence for nerve-nerve purinergic synaptic transmission was published in two papers in Nature in 1992. Synaptic potentials in the coeliac ganglion and in the medial habenula in the brain were reversibly antagonised by suramin, a P2X antagonist. Since then, many articles have described either the distribution of various P2 receptor subtypes in the brain and spinal cord or electro-physiological studies of the effects of purines in brain slices, isolated nerves and glial cells (23). Synaptic transmission has also been found in the myenteric plexus and in various sensory, sympathetic and pelvic ganglia. Adenosine, produced by the ectoenzymatic breakdown of ATP, acts through presynaptic P1 receptors to inhibit the release of excitatory neurotransmitters in both the peripheral and the central nervous systems. P2Y receptors are expressed on both nonmyelinating and myelinating Schwann cells.

In the brain, purinergic signalling is involved in the regulation of a variety of physiological and pathophysiological processes, including development and nervous tissue remodelling following trauma, stroke, ischaemia or neurodegenerative disorders (23). Agonists and antagonists of adenosine and ATP are being explored as therapeutic agents for a number of neurological conditions. For example, 
microinjection of ATP analogues into the prepiriform cortex induces generalised motor seizures. $\mathrm{P} 2 \mathrm{X}_{2}, \mathrm{P} 2 \mathrm{X}_{4}$ and $\mathrm{P} 2 \mathrm{X}_{6}$ receptors are expressed in the prepiriform cortex, suggesting that a $\mathrm{P} 2 \mathrm{X}$ receptor antagonist may have potential as a neuroleptic agent. The hippocampus of chronic epileptic rats shows abnormal responses to ATP associated with increased expression of $\mathrm{P} 2 \mathrm{X}_{7}$ receptors; it has been suggested that purinergic receptors (perhaps on microglia) may participate in the pathophysiology of temporal lobe epilepsy.

In nervous tissue, trophic factors ensure neuronal viability and regeneration. Neuronal injury releases fibroblast growth factor, epidermal growth factor and platelet-derived growth factor. In combination with these growth factors, ATP can stimulate astrocyte proliferation, contributing to the process of reactive astrogliosis and to hypertrophic/hyperplastic responses. P2Y receptor antagonists have been proposed as potential neuroprotective agents in the cortex, hippocampus and cerebellum, by modulation of kainate and AMPA-induced currents, excessive activation of glutamate receptor systems being implicated in neuronal cell death associated with stroke, epileptic seizures and neurodegenerative diseases such as Alzheimers, Parkinson's, Huntington's and amyotrophic lateral scoliosis $(\underline{A L S})$. P2 receptors have been claimed to mediate neuroprotective effects in the cerebellum and the possibility of the therapeutic use of $\mathrm{P} 2$ receptor agonists as neuroprotective agents raised. Upregulation of $\mathrm{P} 2 \mathrm{X}_{1}$ and $\mathrm{P} 2 \mathrm{X}_{2}$ receptors after cerebellar lesions has been reported. Purine derivatives are in clinical trials as memory-enhancing agents in Alzheimers disease; two of these, propentofylline and AIT-082 appear to act as trophic effectors, increasing the production of neurotrophic factors in brain and spinal cord. It has been reported that aluminium can produce Alzheimer-like symptoms and a mechanism has been proposed whereby the aluminium binds to ATP to act on P2 purinoceptors leading to formation of amyloid fibrils. Adenosine is claimed to have a protective effect in a rat model of Parkinson's disease, perhaps by upregulating antioxidant states and reducing dopamine loss. Blockade of $\mathrm{A}_{2 \mathrm{~A}}$ (P1) receptors antagonises parkinsonian tremor in the rat tacrine model by actions on specific striated regions. Increased $A_{2 A}$ receptors in the brain of Parkinson's disease patients with dyskinesias has been described recently, which reinforces the 
notion that $\mathrm{A}_{2 \mathrm{~A}}$ receptor antagonists may be useful for the treatment of Parkinson's disease and levodopa-induced dyskinesias.

ATP inhibits the release of the excitatory transmitter, glutamate, and stimulates the release of the inhibitory transmitter, GABA, from hippocampal nerves. In addition, ATP coreleased with glutamate induces long-term potentiation (LTP) in CA1 neurons associated with learning and memory (24). Nanomolar concentrations of ATP induce long-lasting enhancement of LTP in hippocampal neurons; the P2 antagonist, suramin, inhibits activity of the ectoenzyme, apyrase, which has been shown to participate in the mechanisms of memory acquisition. It has been suggested that ATP coreleased with glutamate, activates CA1 pyramidal hippocampal neurones, allowing calcium to enter postsynaptic cells and thereby inhibiting the effectiveness of NMDA receptors in inducing LTP. Since P2X receptors contribute to synaptic transmission, mainly at low frequencies of stimulation, they may act as a dynamic low-frequency filter, preventing weak stimuli from inducing long-lasting changes in synaptic efficacy. Large rises in $\left[\mathrm{Ca}^{2+}\right]_{\mathrm{i}}$ in CA1 neurons induce LTP, but small rises induce long-term depression (LTD). ATP and activation of glutamate NMDA receptors leads to potentiation of LTP-CA1 neurons (24) in keeping with the synergism that often occurs between cotransmitters (23). There is expression of functional $\mathrm{P} 2 \mathrm{X}$ receptor channels in the axons of CA3 neurons branching to their postsynaptic targets and predominantly in nerve terminals forming synapses with interneurons. ATP released from astrocytes acts as an activity-dependent signalling molecule in neurone-glia communication, resulting in astrocyte $\mathrm{Ca}^{2+}$ waves and synaptic modulation; neuron-glia crosstalk may represent an integral part of activity-dependent plasticity of neural networks. Clearly there are multiple roles for $\mathrm{P} 2$ and $\mathrm{P} 1$ receptors in relation to learning and memory, but the way that therapeutic manipulation of purinergic mechanisms can be utilized to improve these functions is still unresolved. Higher order cognitive functions, including hearing and memory in the prefrontal cortex, also involve purinergic signalling. Adenosine-related compounds might prove helpful in the treatment of memory disorders and impaired intellectual performance related to caffeine intake.

ATP injected into the supraoptic nucleus of the hypothalamus has antidiuretic effects, perhaps through release of arginine 
vasopressin via $\mathrm{P} 1$ receptors. Purinergic and adrenergic synergism for vasopressin and oxytocin release is consistent with ATP cotransmission in the hypothalamus. Purinergic signalling appears to play a significant role in the regulation of body temperature during fever by central hypothalamic and brainstem nuclei. Functional interactions seem likely to occur between purinergic and nitrergic neurotransmitter systems; they may be important for regulation of hormone secretion and body temperature at the hypothalamic level and for cardiovascular and respiratory control at the level of the brainstem. ATP is coreleased with GABA or noradrenaline to act on P2 receptors which are strongly expressed in most nuclei in the hypothalamus, including arcuate, paraventricular, retrochiasmatic, supraoptic, ventromedial and dorsomedial.

$\mathrm{P} 2 \mathrm{X}$ and $\mathrm{GABA}_{\mathrm{A}}$ receptors play an important role in $\mathrm{CO}_{2}$ chemoreception and are involved in mediation of the ventilatory response to hypercapnia. P2X receptors expressed in neurons in the trigeminal mesencephalic nucleus may be involved in the processing of proprioceptive information. The nucleus tractus solitarius (NTS) is a major integrative centre in the brain stem involved in reflex control of the cardiovascular system; stimulation of $\mathrm{P} 2 \mathrm{X}$ receptors in the NTS evokes hypotension with decrease in both cardiac output and total peripheral resistance. Evaluation of the roles of purinergic signalling in processing of the sympathoexcitatory component of the chemoreflex at the NTS level may illuminate the mechanisms underlying the sympathetic overactivity observed in pathophysiological conditions such as hypertension, obstructive sleep apnea and heart failure.

In the striatum, extracellular ATP and adenosine are involved in the regulation of the feeding-associated mesolimbic neuronal activity in an antagonistic manner. PPADS suppresses the feeding-evoked dopamine release in the nucleus accumbens, a brain region regarded as important for the regulation of appetite behaviour and reinforcement. Adenosine-dopamine interactions in the ventral striatum have been implicated in schizophrenia and $\mathrm{A}_{2 \mathrm{~A}}$ agonists proposed as antipsychotics. A hypothesis has been put forward where dysfunction of purinergic signalling (for example, decreased ATPase activity in erythrocytes, leading to increased levels of ATP and decreased adenosine) may lead to schizophrenia. 
It has been claimed that purinergic signalling dysfunction (perhaps largely reduced adenosinergic activity) is involved in mania and aggressive behaviour. Endogenous ATP has been claimed to be involved in the regulation of anxiety via stimulation of $\mathrm{P}_{2} \mathrm{Y}_{1}$ receptors in the dorsomedial hypothalamus in rats. Chronically administered guanosine has anticonvulsant, amnesic and anxiolytic effects in mice, perhaps associated with modulation of glutamatergic excitation. There is a growing body of evidence suggesting that adenosine is involved in drug addiction and withdrawal, and that purinergic signalling pathways may offer novel targets for the therapeutic treatment of addiction to opioids.

Multiple P2X and P2Y receptors have been identified on single cerebellar granule cells. It has been reported that ATP continuously modulates the cerebellar circuit by increasing the inhibitory input to Purkinje neurons, probably via $\mathrm{P} 2 \mathrm{X}_{5}$ and $\mathrm{P} 2 \mathrm{Y}_{2}$ and/or $\mathrm{P}_{2} \mathrm{Y}_{4}$ receptor subtypes, thus decreasing the main cerebellar output activity which contributes to locomotor coordination.

Spinal cord traumas are a major health problem. ATP- $\mathrm{MgCl}_{2}$ has been shown to decrease lipid peroxidation in spinal cord injury and protect the spinal cord from secondary injury after trauma; it was concluded that ATP- $\mathrm{MgCl}_{2}$ should be explored for the treatment of spinal cord injuries in conjunction with other treatment modulators.

Phenylketonuria is an innervated deficiency of phenylalanine hydroxylase activity in the liver, which leads to increased brain levels of phenylalanine and its metabolites, leading to permanent brain damage in the early period of postnatal brain development. Phenylalanine has been shown to inhibit ATP diphosphohydrolase resulting in increase in ATP levels, perhaps the neurotoxic mechanism underlying brain damage in this disease.

\section{Glial cells}

ATP is an extracellular signalling molecule between neurones and glia. ATP released by cellular damage and from astrocytes may be important in triggering cellular responses to trauma and ischaemia by initiating and maintaining reactive astrogliosis, which involves 
striking changes in proliferation and morphology of astrocytes and microglia. Some of the responses to ATP released during brain injury are neuroprotective, but in some cases ATP contributes to the pathophysiology initiated after trauma. It has been claimed that $\mathrm{P}_{2} \mathrm{Y}_{2}$ receptors activate neuroprotective mechanisms in astrocytic cells. In contrast, experimental infusion of ATP into nucleus accumbens or cerebral hemisphere of rats suggests that purines might be a signal for induction of malignant brain tumours. Multiple P2X and P2Y receptor types are expressed by astrocytes, oligodendrocytes and microglia. P2Y receptors mediate reactive astrogliosis via induction of Cox-2 and P2Y receptor antagonists might counteract excessive Cox-2 activation in both acute and chronic neurological disease. P2 receptors also mediate regulation of Cox-2 in microglia. IL-1 $\beta$ induced astrocyte activation is regulated by purinergic signalling; this is compatible with the hypothesis that nucleotides released under inflammatory conditions activate autocrine or paracrine signalling pathways that modulate inflammation. ATP can activate $\mathrm{P} 2 \mathrm{X}_{7}$ receptors in astrocytes to release glutamate, GABA and ATP, which regulate the excitability of neurons. ATP release during neuronal excitation or injury can enhance the inflammatory effects of cytokines and prostaglandin $\mathrm{E}_{2}$ in astrocytes and may contribute to chronic inflammation seen in Alzheimer's disease. Astrocytic gap junctions are involved in the neuroprotective process, in particular to protect neurons from oxidative stress and glutamate toxicity.

Microglia, immune cells of the CNS, are also activated by purines and pyrimidines to release inflammatory cytokines such as interleukins $1 \beta$ and 6 and tumour necrosis factor (TNF- $\alpha$ ); activated microglia can also act as scavenger cells that induce apoptosis in damaged neurons by releasing toxic factors, including NO. Thus, while microglia may play an important role against infection in the CNS, overstimulation of this immune reaction may accelerate the neuronal damage caused by ischaemia, trauma or neurodegenerative diseases such as Alzheimer's and Parkinson's disease, HIV, encephalopathy, multiple sclerosis and amyotrophic lateral scoliosis (ALS), which exhibit microglial proliferation and activation (25). These authors showed that ATP inhibits cytokine release from lipopolysaccharide-activated microglia via $\mathrm{P} 2 \mathrm{Y}$ receptors and suggested that $\mathrm{P} 2 \mathrm{Y}$ agonists may be a potential treatment for toxic 
immunoreactions. Recent studies have shown that $\mathrm{P} 2 \mathrm{X}_{4}$ receptors induced in spinal microglial gate tactile allodynia after nerve injury (26) (see section on Pain). P2X $\mathrm{X}_{7}$ receptors mediate superoxide production in primary microglia and are upregulated in a transgenic model of Alzheimers' disease, particularly around $\beta$-amyloid plaques. Stimulation of microglial $\mathrm{P} 2 \mathrm{X}_{7}$ receptors also leads to enhancement of interferon- $\gamma$ (IFN- $\gamma$ )-induced type II nitric oxide synthase activity. $\mathrm{P} 2 \mathrm{X}_{7}$ receptors may therefore provide a therapeutic target for inflammatory responses seen in neurodegenerative disorders.

$\mathrm{P} 2$ receptors are expressed by oligodendrocytes. However, while $\mathrm{P} 2$ receptors on oligodendrocytic progenitor cells mediate increase in $\left[\mathrm{Ca}^{+}\right]_{\mathrm{i}}$ it is adenosine that appears to mediate the formation of myelin, raising the possibility that activation of purinoceptors may offer new approaches to the treatment of demyelinating diseases in the CNS, such as multiple sclerosis. P2X receptors expressed by Schwann cells may regulate the synthesis and release of cytokines during pathophysiological events.

\section{ONCOLOGY}

The anticancer activity of adenine nucleotides was first described by Rapaport in 1983. Intraperitoneal injection of ATP into tumourbearing mice resulted in significant anticancer activity against several fast-growing aggressive carcinomas (4). ATP inhibits the growth of murine colonic adenocarcinoma and human pancreatic carcinoma in mice as well as inhibiting the associated weight loss. In a recent comprehensive review about the use of ATP for the treatment of advanced cancer (27), evidence was presented that: extracellular ATP inhibits the growth of a variety of human tumours, including prostate, breast, colon, liver, ovarian, colorectal, oesophageal and melanoma cancer cells, partly by mediating apoptotic cancer cell death; ATP administration induces resistance of non-malignant tissue to chemo- and radiation therapy; ATP has pronounced anticachexia effects, particularly in older patients, reducing weight loss, anorexia, and hormonal aberrations, largely via its ability to expand blood plasma ATP pools. It was concluded that preclinical data supporting utilization of ATP in the treatment of advanced cancers, along with 
Phase I and II human trials indicate that ATP has a future place as a useful anticancer agent. The combination of ATP administration with other anticancer modalites is beginning to be explored.

Growth of prostate-cancer cells in vitro is inhibited by up to 90\% by ATP via P2 receptors, although it is not yet clear which subtype mediates this effect and whether it is a directly antiproliferative effect or a proapoptotic effect (28). Phase I clinical trials have shown that ATP infusion in patients with advanced cancer is feasible, but is limited by chest tightness and dyspnoea, probably due to conversion to adenosine.

A phase II trial has been carried out in patients with non-small cell lung cancer, showing that intravenous ATP administered for 96 hours at 4-week intervals reduced weight loss and improved muscle strength and quality of life, as well as inducing cancer cell death (4).

A combination of interferon- $\gamma$ and ATP is being explored for the treatment of acute myeloid leukaemia. ATP induced irreversible damage of leukemic cells without injuring normal hemopoietic stem cells, and it was suggested that it could be useful for purging the residual leukaemic cells in autologous bone marrow transplantation. Extracellular ATP suppresses proliferation and induction of differentiation of human HL-60 leukaemia cells, partly mediated by adenosine (after breakdown of ATP) and partly by ATP. P2 $\mathrm{X}_{7}$ receptor expression in the evolutive form of chronic $\beta$ lymphocyte leukaemia has been identified; ATP decreased proliferation of lymphocytes in this form of leukaemia. $\beta$-cell chronic lymphocyte leukaemia is unique in showing a three-fold increased incidence in closely related family members compared to other lymphoproliferative diseases; a candidate gene for this familial incidence is the $\mathrm{P} 2 \mathrm{X}_{7}$ gene.

Recent studies from our laboratory have analysed the P2 receptor subtypes that contribute to ATP suppression of malignant melanomas (29) in basal and squamous cell tumours (30) and prostate and bladder cancers (28). In general, $\mathrm{P} 2 \mathrm{Y}_{1}$ and $\mathrm{P} 2 \mathrm{Y}_{2}$ receptors mediate proliferative or antiproliferative effects, $\mathrm{P} 2 \mathrm{X}_{5}$ receptors mediate cell differentiation, which in effect is antiproliferative and $\mathrm{P} 2 \mathrm{X}_{7}$ receptors mediate apoptotic cell death. ATP administration is particularly effective in treating bladder tumours when combined with the more commonly used anticancer drug mitomycin. 
Intracarotid administration of ATP, selectively increases blood flow in transplanted, malignant gliomas and suggests that this might enhance the delivery of anti-cancer agents to malignant brain tumours.

\section{PAIN}

The involvement of ATP in the initiation of pain was recognised early, by Collier et al. in 1966 and Bleehan \& Keele in 1977. A major advance was made when the $\mathrm{P}_{2} \mathrm{X}_{3}$ ionotropic receptor was cloned in 1995 and shown to be localised predominantly in the subpopulation of small nociceptive sensory nerves that label with isolectin IB4 in dorsal root ganglia. Later, Burnstock (31) put forward a unifying purinergic hypothesis for the initiation of pain associated with causalgia, reflex sympathetic dystrophy, angina, migraine and cancer pain, which has been followed by an increasing number of papers expanding on this concept for acute, inflammatory, neuropathic and visceral pain. Sensory terminals are sensitive to ATP and $\alpha, \beta$ methylene ATP in the tongue, tooth pulp, bladder (32), ureter (33) and gut (10). Both $\mathrm{P} 2 \mathrm{X}_{3}$ (homomultimer) and $\mathrm{P} 2 \mathrm{X}_{2 / 3}$ (heteromultimer) receptors mediate nociceptive afferent responses, but the proportions vary in different organs. P2Y receptors have also been demonstrated in a subpopulation of sensory neurons which colocalise with P2X3 receptors.

The search is on for selective $\mathrm{P} 2 \mathrm{X}_{3}$ and $\mathrm{P} 2 \mathrm{X}_{2 / 3}$ receptor antagonists that do not degrade in vivo. PPADS is a non-selective P2 antagonist, but has the advantage that it dissociates about 100-10,000 times more slowly than other known antagonists. The trinitrophenylsubstituted nucleotide, TNP-ATP, is selective and very potent at both $\mathrm{P} 2 \mathrm{X}_{3}$ and $\mathrm{P} 2 \mathrm{X}_{2 / 3}$ receptors. A-317491 is a potent and selective non-nucleotide antagonist of $\mathrm{P} 2 \mathrm{X}_{3}$ and $\mathrm{P} 2 \mathrm{X}_{2 / 3}$ receptors and it reduces chronic inflammatory and neuropathic pain in the rat (34). Antisense oligonucleotides have been used to downregulate the $\mathrm{P}_{2} \mathrm{X}_{3}$ receptor and in models of neuropathic (partial sciatic nerve ligation) and inflammatory (complete Freund's adjuvant) pain, inhibition of the development of mechanical hyperalgesia as well as significant reversal of established hyperalgesia, were observed within 2 days of 
treatment. Combined antisense and RNAi-mediated treatment for specific inhibition of the recombinant rat $\mathrm{P} 2 \mathrm{X}_{3}$ receptor appears to be promising for pain therapy. Cytotoxic targeting using IB4-saporin conjugate of isolectin IB4-binding nociceptive sensory neurons decreases the severity to noxious stimuli. Antagonism of $\mathrm{P} 2 \mathrm{X}_{1}$ and $\mathrm{P} 2 \mathrm{X}_{3}$ receptors by phenol red has recently been reported and shown to cause significant increase in pressure and volume threshold required to initiate the micturition reflex in female urethraanaesthetised rats. Modulation of neurotransmission through $\mathrm{P}_{2} \mathrm{X}_{3}$ receptors in central and peripheral nervous systems may contribute to the anaesthesia and analgesia produced by barbiturates. Tetramethylpyrazine, a traditional Chinese medicine, used as an analgesic for dysmenorrhoea, inhibited significantly the first phase of nociceptive behaviour induced by $5 \%$ formation and attenuated slightly the second phase in the rat hindpaw pain model. Interactions between vanilloid and metabotropic P2Y receptors are also being explored in terms of treatments for chronic pain and thermal hypersensitivity.

For neuropathic pain, the tactile allodynia that follows peripheral nerve injury is reduced by A-134974, a novel adenosine kinase inhibitor acting at spinal sites. Endogenous ATP acting on P2X receptors appears to be necessary for the induction of the postoperative pain characterised by mechanical allodynia. Upregulation of P2Y1 receptor expression in DRG occurs after transection of sciatic nerves. P2X4 receptors are induced in spinal microglia that appear to gate tactile allodynia after nerve injury (26). Intraspinal administration of p38 inhibitor suppressed allodynia, which suggests that neuropathic pain hypersensitivity depends on the activation of p38 signalling pattern in microglia in the dorsal horn following peripheral nerve injury. Suramin inhibits spinal cord microglia activation and long-term hyperalgesia induced by formalin injection. Analgesic effects of intrathecal administration of P2Y receptor agonists UTP and UDP in normal and the neuropathic pain rat model have been reported suggesting that $\mathrm{P}_{2} \mathrm{Y}_{2}$ (and $\mathrm{P} 2 \mathrm{Y}_{4}$ ) and $\mathrm{P}^{2} \mathrm{Y}_{6}$ receptors, in contrast to $\mathrm{P} 2 \mathrm{X}$ receptors, produce inhibitory effects in spinal pain transmission. Purinergic mechanisms are also beginning to be explored in relation to cancer pain. 


\section{RESPIRATORY SYSTEM}

Purinergic compounds are being explored for the treatment of cystic fibrosis, to improve the clearance of secretions from the bronchi in chronic obstructive pulmonary disease (COPD) and for sputum expectoration in smokers (35). The long lasting $\mathrm{P}_{2} \mathrm{Y}_{2}$ analogue, INS 37217, increases the duration of mucociliary clearance and therefore has significant advantages over other $\mathrm{P}_{2} \mathrm{Y}_{2}$ agonists for the treatment of cystic fibrosis. $\mathrm{P} 2 \mathrm{X}_{4}$ receptors have also been identified on lung epithelial cells and appear to be involved in regulation of ciliary beat, manipulation of which may also be of therapeutic benefit for cystic fibrosis. Recent evidence supports the view that vagal afferent purinergic signalling may be involved in the hyperactivity associated with asthma and COPD (36).

Pulmonary hypertension can be a problem in patients with COPD which also has other causes; it is a life-threatening condition, and intravenous ATP infusion produces a significant decrease in mean pulmonary arterial pressure and pulmonary vascular resistance without changing the mean systemic arterial pressure.

The use of theophylline, an adenosine-receptor antagonist, as an antiasthmatic agent has focused attention on the development of novel $\mathrm{P} 1$ receptor antagonists as asthmatic medications.

Erythromycin is a widely used antibiotic for the treatment of upper and lower respiratory tract infections. One of the most conspicuous effects of erythromycin is the suppression of fluid secretion from bronchial epithelial cells in the treatment of bronchitis. Erythromycin has been shown to block the P2X receptormediated $\mathrm{Ca}^{2+}$ influx and may represent one mechanism by which it exerts its antisecretory effects in the treatment of chronic respirator tract infections.

The ventrolateral medulla (VLM) contains a network of respiratory neurons that are responsible for the generation and shaping of respiratory rhythm; it also functions as a chemoreceptive area mediating the ventilating response to hypercapnia. Evidence has been presented that ATP acting on $\mathrm{P}_{2} \mathrm{X}_{2}$ receptors expressed in VLM neurones influences these functions. A potentially important role for $\mathrm{P} 2$ receptor synaptic signalling in respiratory motor control 
is suggested by the multiple physiological effects of ATP in hypoglossal activity associated with the presence of $\mathrm{P} 2 \mathrm{X}_{2}, \mathrm{P} 2 \mathrm{X}_{4}$ and $\mathrm{P} 2 \mathrm{X}_{6}$ receptor mRNA in nucleus ambiguous and the hypoglossal nucleus.

The pneumovirus respiratory syncytial virus (RSV) is the most common cause of lower respiratory tract disease in infants and children. It has a detrimental inhibitory effect on alveolar clearance, an effect that appears to be mediated by UTP, perhaps released by the bronchoalveolar epithelium in response to infection. This suggests that $\mathrm{P} 2 \mathrm{Y}_{2}$ receptor antagonists may be useful for the treatment of severe RSV broncheotitis.

Alveolar macrophages play a pivotal role in the development of chronic lung inflammatory reactions such as idiopathic pulmonary fibrosis, silicosis, asbestosis, hypersensitivity pneumonitis, sarcoidosis and myobacterium tuberculosis. $\mathrm{P}_{2} \mathrm{X}_{7}$ receptors are expressed in alveolar macrophages, which upon stimulation activate the proinflammatory IL- 1 to IL-5 cytokine cascade and the formation of multinucleated giant cells, a hallmark of granulomatous reactions (15). $\mathrm{P} 2 \mathrm{X}_{7}$ receptors may be a relevant target for therapeutic intervention in lung hypersensitivity reactions associated with chronic inflammatory responses.

The need to support the failing lung (acute respiratory distress syndrome [ARDS]) with mechanical ventilation is potentially lifesaving, but unfortunately, alveolar overdistension and pulmonary shear stress may cause lung injury (ventilator-induced lung injury, VILI), increasing bronchoalveolar lavage leading to lung oedema. It has been suggested that VILI may involve stretch-associated release of ATP from neuroepithelial cell bodies (NEBs) and may therefore be a therapeutic target for this condition.

\section{SPECIAL SENSES}

\section{Eye}

Purinergic signalling is widespread in the eye and novel therapeutic strategies being developed for glaucoma, dry eye and retinal detachment (37). 
$\mathrm{ATP}$, acting via both $\mathrm{P} 2 \mathrm{X}$ and $\mathrm{P} 2 \mathrm{Y}$ receptors, moduates retinal neurotransmission, affecting retinal blood flow and intraocular pressure. The ATP analogue $\beta, \gamma$-methylene ATP is more effective in reducing intraocular pressure $(40 \%)$ than muscarinic agonists such as pilocarpine $(25 \%)$ and b-adrenoceptor blockers (30\%), raising the potential for the use of purinergic agents in glaucoma. Suramin, a P2 receptor antagonist, has been shown to inhibit the fibrotic wound healing reactions that sometimes follow trabeculectomies for surgically treating eyes with glaucoma. Topical application of diadenosine tetraphosphate $\left(\mathrm{Ap}_{4} \mathrm{~A}\right)$ has been proposed for the lowering of intraocular pressure in glaucoma.

$\mathrm{P} 2 \mathrm{Y}_{2}$ receptor activation increases salt, water and mucus excretion, and thus represents a potential treatment for dry eye conditions (35). In the pigmented layer of the retina, $\mathrm{P} 2 \mathrm{Y}_{2}$ receptor activation promotes fluid absorption, and may be involved in retinal detachment. INS 37217, a long lasting synthetic $\mathrm{P} 2 \mathrm{Y}_{2}$ receptor agonist, stimulates the retinal pigment epithelium by activating $\mathrm{P}_{2} \mathrm{Y}_{2}$ receptors at the apical membrane and in vivo treatment enhances the rate of subretinal fluid reabsorption in experimentally induced retinal detachments and may be useful for treating a variety of retinal diseases that result in fluid accumulation in the subretinal space. Reactive responses of Müller cells occur within 24 hours of retinal detachment. Suramin inhibits some of these responses and may provide a therapeutic candidate to limit the detrimental effects of immune cell activation and Müller cell gliosis during retinal detachment.

ATP and UTP restore the rates of both net $\mathrm{Cl}^{-}$and fluid secretion in adenovirus type 5 infected conjunctival tissues and are considered as potential therapeutic modulators for the treatment of various transport defects encountered in ocular tissues in diseased and/or inflamed states.

UTP and diadenosine tetraphosphate $\left(\mathrm{Ap}_{4} \mathrm{~A}\right)$ accelerate wound healing in the rabbit cornea, by regulating the rate of epithelial cell migration.

The UPL rat is a dominant hereditary cataract model derived from Sprague-Dawley rats and has been used to show that $\mathrm{Ca}^{2+}$ ATPase expression increases, while ATP control decreases in lenses 
during the development of the cataract and opacification; disulfirom and aminoguanidine, which inhibit inducible NO and scavenge reactive oxygen species, attenuate the decrease in ATP, resulting in a delay in cataract development.

\section{Ear}

In the auditory system ATP, acting via P2Y receptors, depresses sound-evoked gross compound action potentials in the auditory nerve and the distortion product otoacoustic emission, the latter being a measure of the active process of the outer hair cells (38). P2X splice variants are found on the endolymphatic surface of the cochlear endothelium, an area associated with sound transduction. Both P2X and $\mathrm{P} 2 \mathrm{Y}$ receptors have been identified in the vestibular system. ATP may regulate fluid homeostasis, cochlear blood flow, hearing sensitivity and development, and thus may be useful in the treatment of Ménières disease, tinnitus and sensorineural deafness.

Excessive noise can irreversibly damage hair cell stereocilia leading to deafness. Data has been presented that release of ATP from damaged hair cells is required for $\mathrm{Ca}^{2+}$ wave propagation through the support cells of the organ of Corti, involving P2Y receptors, and this may constitute the fundamental mechanism to signal the occurrence of hair cell damage. ATP is claimed to mitigate the effects of noise trauma, although the primary mechanisms involved are not clear.

\section{Nasal organ}

Purinergic receptors have been described in the nasal mucosa, including the expression of $\mathrm{P} 2 \mathrm{X}_{3}$ receptors on olfactory neurones (39). Enhanced sensitivity to odours in the presence of P2 purinergic antagonists suggests that low-level endogenous ATP normally reduces odour responsiveness. It appears that the induction of heat-shock proteins by noxious odour damage can be prevented by the in vivo administration of $\mathrm{P} 2$ receptor antagonists. The predominantly suppressive effect of ATP in odour responses could play a role in the reduced odour sensitivity that occurs during acute exposure to noxious fumes and may be a novel neuroprotective mechanism. 


\section{UROGENITAL SYSTEM}

In the normal human bladder, atropine will block at least 95\% of parasympathetic nerve-mediated contraction, indicating that its innervation is predominantly cholinergic; purinergic signalling is responsible for the atropine-resistant component of contraction (40). There are a number of examples of the purinergic component of cotransmission increasing in pathological conditions. One is that purinergic nerve-mediated contraction of the human bladder is increased to $40 \%$ in pathophysiological conditions such as interstitial cystitis, outflow obstruction, idiopathic detrusor instability and probably also neurogenic bladder. ATP release from bladder epithelial cells from patients with interstitial cystitis is significantly greater than from healthy cells and there is increase of expression of $\mathrm{P} 2 \mathrm{X}_{2}$ and $\mathrm{P} 2 \mathrm{X}_{3}$ receptors in urothelial cells. $\mathrm{P} 2 \mathrm{X}_{1}$ receptor subtype expression markedly increased in obstructed bladder and in the absence of $\mathrm{P} 2 \mathrm{X}_{3}$ receptors in mouse knockouts, the bladder is hyperactive.

Purinergic signalling also plays a role in afferent sensation from the bladder. ATP is released from urothelial cells when the bladder is distended. Sensory-nerve recording has indicated that $\mathrm{P} 2 \mathrm{X}_{3}$ receptors are involved in mediating the nerve responses to bladder distension, providing mechanosensory feedback involving both the micturition reflex and pain (32). This, too, might be a potential target for pharmacological manipulation in the treatment of detrusor instability.

In ageing rats there is an increased sensitivity of the bladder to ATP, but no change in response to acetylcholine or potassium chloride. Comparable results have been found showing increased purinergic, but not cholinergic neurotransmission, to ageing human bladder smooth muscle. Activation of $\mathrm{P} 2$ receptors in the brain stem (both periaqueductal grey matter and Barrington's nucleus/locus ceruleus) generate patterns of activity in the parasympathetic innervation of the bladder. In patients with idiopathic detrusor instability, there is abnormal purinergic transmission in the bladder; this may account for some of the symptoms and provide a novel therapeutic target for treatment of overactive bladder (41). Voiding dysfunction involves $\mathrm{P}_{2} \mathrm{X}_{3}$ receptors in awake chronic spinal cord injured rats, which raises the possibility that $\mathrm{P} 2 \mathrm{X}_{3}$ antagonists might 
be useful for the treatment of neurogenic bladder dysfunction. Drugs that alter ATP release or breakdown might also be therapeutic targets. Expression of P2 receptors in bladder urethelium, as well as nerve and smooth muscle, changes in a cat model of interstitial cystitis and may be linked with painful bladder symptoms.

Normal penile erectile function is dependent upon a delicate balance between contracting and relaxing factors in the corpus cavernosum smooth muscle, which are modulated by signalling from both nerves and endothelial cells. Evidence has accumulated to support a pivotal role for non-adrenergic, non-cholinergic neurotransmitters. NO plays a central role in mediating cavernosal smooth muscle relaxation, but other neurotransmitters can modulate this action and may play a role in erectile dysfunction. ATP potently relaxes cavernosal smooth muscle strips in vitro, an action pharmacologically consistent with P2Y receptors. Indeed, P2Y receptors are present on both cavernosal smooth muscle cells and endothelial cells, and ATP is released from a subpopulation of the cavernosal nerves. It appears that smooth muscle relaxation is caused both by ATP acting directly on the cavernosal smooth muscle cells and indirectly, mediated by NO released from the endothelial cells. ATP-mediated cavernosal relaxation is impaired in diabetes mellitus (independent of NO) implying that purinergic signalling may be involved in the pathophysiology of erectile dysfunction.

In humans, ATP induces a significant increase in sperm fertilizing potential and this provides a rationale for the use of ATP for treatment of spermatozoa during in vitro fertilization. Knockout mice lacking $\mathrm{P} 2 \mathrm{X}_{1}$ receptors appear normal, but fail to breed and this is associated with loss of the purinergic component of sympathetic cotransmissin in the vas deferens; these findings raise the possibility of developing non-hormonal ways of regulating male fertility. Differential, stagedependent immunostaining for P2X receptors during spermatogenesis in the adult rat testes has been described (42) and opens up the possibility of purinergic targets for both fertility and contraception. Evidence has been presented that glyolysis has an unexpectedly important role in providing the ATP required for sperm motility throughout the length of the sperm flagellum.

The potential role of $\mathrm{P}_{2} \mathrm{X}_{3}$ receptors in mechanosensory transduction has already been mentioned in relation to the bladder 
(9). However, there is increasing evidence that this is not an isolated phenomenon and that ATP released from the epithelial lining of other organs such as the ureter, gut or bile duct following distension may act on $\mathrm{P} 2 \mathrm{X}_{3}$ receptors on afferent nerves in the subepithelial plexuses to provide sensory feedback and, in the case of the ureter, renal colic pain (see section on Pain). $\mathrm{P} 2 \mathrm{X}_{3}$ receptors have been found on the suburothelial nerve plexus and both the human and guinea-pig ureter have been shown to release ATP in a pressuredependent fashion when distended. This ATP release is abolished when the urothelium is removed, and sensory nerve-recording studies during ureteral distension demonstrate purinergic involvement, suggesting that specific $\mathrm{P} 2 \mathrm{X}_{3}$ antagonists may have efficacy in alleviating renal colic.

Synergistic effects of ATP and oxytocin in increasing $\left[\mathrm{Ca}^{2+}\right]_{\mathrm{i}}$ in mouse mammary myoepithelial cells suggests that activation of purinergic receptors may facilitate myoepithelial cell contraction in the milk-ejection response. $\mathrm{P} 2 \mathrm{Y}_{2}$ receptors on apical and basolateral membranes appear to be involved.

Micromolar concentrations of ATP stimulate biphasic change in transepithelial conductance in the human uterine cervix, phase 1 mediated by the $\mathrm{P} 2 \mathrm{Y}_{2}$ receptor, phase II by the $\mathrm{P} 2 \mathrm{X}_{4}$ receptor. Given the potential role of ATP regulation of cervical paracellular permeability for human fertility, contraception and health, these findings may have clinical significance and may lead to the development of drugs that can target specific signalling pathways in the cervix.

\section{FUTURE DEVELOPMENTS}

Although in its infancy, the clinical manipulation of purinergic signalling has begun. Several clinically relevant pharmacological interventions are already part of day-to-day practice. However, one of the main reasons why we do not yet have more purinergic therapies in our formularies is the current sparsity of receptorsubtype-specific agonists and antagonists that are effective in vivo. In addition to the development of selective agonists and antagonists 
fro the different $\mathrm{P} 2$ receptor subtypes, therapeutic strategies are likely to include agents that control the expression of $\mathrm{P} 2$ receptors, inhibitors of extracellular breakdown of ATP and enhancers or inhibitors of ATP transport. Investigating the interactions of purinergic signalling with other established signalling systems will also be important.

\section{REFERENCES}

(1) Burnstock, G. and Knight, G. E. (2004): Int. Rev. Cytol. 240: 31-304.

(2) Ralevic, V. and Burnstock, G. (1998): Pharmacol. Rev. 50: 413-492.

(3) Burnstock, G. (2002): Clinical Medicine 2: 45-53.

(4) Agteresch, H. J.; Dagnelie, P. C.; van der Berg, J. W. O. and Wilson, J. H. (1999): Drugs 58: 211-232.

(5) Bunnstock, G. (2002): Arteriosclerosis, Thrombosis and Vascular Biology 22: 364-373.

(6) Yang, A.; Sonin, D.; Jones, L.; Barry, W. H. and Liang, B. T. (2004): Am. J. Physiol 287: H1096-H1103.

(7) Di, V. F. and Solini, A. (2002): Br. J. Pharmacol. 135:831-842.

(8) Greig, A. V. H.; Linge, C.; Terenghi, G.; McGrouther, D. A. and Burnstock, G. (2003): J. Invest. Dermatol. 120: 1007-1015.

(9) Bunnstock, G. (2001): Purinergic signalling in gut. In Abbracchio, M. P. and Williams, M. editors. Handbook of Experimental Pharmacology, Volume 151/ II. Purinergic and Pyrimidinergic Signalling II-Cardiovascular, Respiratory, Immune, Metabolic and Gastrointestinal Tract Function, Springer-Verlag, Berlin, pp. 141-238.

(10) Wynn, G.; Bei, M.; Ruan, H-Z. and Burnstock, G. (2004): Am. J. Physiol Gastrointest Liver Physiol 287: G647-G657.

(11) Galligan, J. J. (2004): Br. J. Pharmacol. 141: 1294-1302.

(12) Burnstock, G. (2001): Trends Pharmacol. Sci. 22: 182-188.

(13) Di Virgilio, F.; Falzoni, S.; Mutini, C.; Sanz, J. M. and Chiozzi, P. (1998): Drug Dev. Res. 45: 207-213.

(14) Lammas, D. A.; Stober, C.; Harvey, C. J.; Kendrick, N.; Panchalingam, S. and Kumararatne, D. S. (1997): Immunity. 7: 433-444.

(15) Lemaire, I. and Leduc, N. (2004): Drug Dev. Res. 59: 118-127.

(16) Waeber, C. and Moskowitz, M. A. (2003): Neurology 61: S9-20.

(17) Hoebertz, A.; Arnett, T. R. and Burnstock, G. (2003): Trends Pharmacol. Sci. 24: 290-297.

(18) KorcoK, J.; Raimundo, L. N.; Ke, H. Z.; Sims, S. M. and Dixon, S. J. (2004): J. Bone Miner. Res. 19: 642-651.

(19) Dell'Antonio, G.; Quattrini, A.; Cin, E. D.; Fulgenzi, A. and Ferrero, M. E. (2002): Artritis Rheum 46: 3378-3385. 
(20) Ryten, M., Yang, S. Y., Dunn, P. M., Goldspink, G., and Burnstock, G. (2004): FASEB J. 18: 1404-1406.

(21) Unwin, R. J., Bailey, M. A., and Burnstock, G. (2003): News Physiol. Sci. 018 : 237-241.

(22) Vonend, O., Turner, C., Chan, C. M., Loesch, A., Dell'Anna, G. C., Srai, S. K., Burnstock, G., and Unwin, R. (2004): Kidney Int. 66: 157-166.

(23) Burnstock, G. (2003): Purinergic receptors in the nervous system. In Schwiebert, E. M., editor. Current Topics in Membranes, Vol. 54. Purinergic Receptors and Signalling, Academic Press, San Diego, pp. 307-368.

(24) Fujil, S., Kato, H., and Kuroda, Y. (2002): Neuroscience 113: 617-628.

(25) Ogata, T., Chuai, M., Morino, T., Yamamoto, H., Nakamura, Y., and Schubert, P. (2003): Brain Res. 981: 174-183.

(26) Tsuda, M., Shigemoto-Mogami, Y., Koizumi, S., Mizokoshi, A., Kohsaka, S., Salter, M. W., and Inoue, K. (2003): Nature 424: 778-783.

(27) Abraham, E. H., Salikhova, A. Y., and Rapaport, E. (2003): Current Topics in Membranes 54: 415-452.

(28) Calvert, R. C., Shabbir, M., Banks, F., Thompson, C. S., Mikhailidis, D. P., Morgan, R., and Burnstock, G. (2004): Anticancer Research 24: 2853-2859.

(29) White, N., Ryten, M., Clayton, E., Butler, P. and Burnstock, G. (2005): Cancer Letters (on-line).

(30) Greig, A. V. H., Linge, C., Healy, V., Lim, P., Clayton, E., Rustin, M. H., McGrouther, D. A., and Burnstock, G. (2003): J. Invest. Dermatol. 121: 315327.

(31) Burnstock, G. (1996): Lancet 347: 1604-1605.

(32) Vlaskovska, M., Kasakov, L., Rong, W., Bodin, P., Bardini, M., Cockayne, D. A., Ford, A. P. D. W., and Burnstock, G. (2001): J. Neurosci. 21: 5670-5677.

(33) Rong, W. and Burnstock, G. (2004): Neuropharmacology 47: 1093-1101.

(34) McGaraughty, S., Wismer, C. T., Zhu, C. Z., Mikusa, J., Honore, P., Chu, K. L., Lee, C. H., Faltynek, C. R., and Jarvis, M. F. (2003): Br. J. Pharmacol. 140: 1381-1388.

(35) YerXa, B. R. (2001): Drug Dev. Res. 52: 196-201.

(36) Adriaensen, D. and Timmermans, J. P. (2004): Curr. Opin. Pharmacol. 4: $207-$ 214.

(37) Pintor, J., Peral, A., Peláez, T., Carracedo, G., Bautista, A., and Hoyle, C. H. (2003). Drug Dev. Res. 59: 136-145.

(38) Sueta, T., Paki, B., Everett, A. W., and Robertson, D. (2003): Hear. Res. 183: 97-108.

(39) Gayle, S. and Burnstock, G. (2004): Cell Tissue Res. (on-line).

(40) Burnstock, G. (2001): Purinergic signalling in lower urinary tract. In Abbracchio, M. P. and Williams, M., editors. Handbook of Experimental Pharmacology, Volume 151/I. Purinergic and Pyrimidinergic Signalling I Molecular, Nervous and Urinogenitary System Function, Springer-Verlag, Berlin, pp. 423-515.

(41) Andersson, K. E. And Hedlund, P. (2002): Urology 60: 13-20.

(42) Glass, R., Bardini, M., Robson, T., and Burnstock, G. (2001): Cells Tissues Org. 169: $377-387$. 